\title{
PENINGKATAN KREATIVITAS PENGAWAS MADRASAH MELALUI DIKLAT
}

Oleh:

1. Hindun (Widyaiswara Ahli Utama Pusdiklat Tenaga Teknis Pendidikan dan Keagamaan

2. Aspina (Widyaiswara Ahli Madya Badan Pengembangan SDM Propinsi Sulawesi Tengah

\begin{abstract}
ABSTRAK
Kreativitas pengawas madrasah (pada jenjang MI, MTs dan MA) sering menjadi masalah terhadap aktivitas pelaksanaan supervisi akademik dan supervisi manajerial, terutama dalam penyusunan instrumen yang digunakan sebagai alat supervisi. Tujuan penulisan karya tulis ini adalah untuk mendeskripsikan pengaruh diklat terhadap peningkatan kreativitas pengawas madrasah. Metodologi dan analisis data yaitu mengambil setting peserta Diklat Teknis Substantif Pengawas Madrasah Madya Angkatan I yang diselenggarakan Pusdiklat Tenaga Teknis Pendidikan dan Keagamaan pada tanggal 31 Mei - 10 Juni 2017. Adapun data diperoleh dari 30 responden peserta diklat angkatan I. Hasil analisis data sebelum diberi materi inti diklat diperoleh nilai yaitu 64,0 dan setelah diberi materi inti diklat terjadi peningkatan nilai yaitu 73,7 . Atau terjadi peningkatan nilai kreativitas sebesar 9,7 setelah diberikan materi inti diklat. Jadi, dapat disimpulkan bahwa Diklat Teknis Substantif Pengawas Madrasah Madya meningkatkan kreativitas pengawas madrasah.
\end{abstract}

Kata kunci: kreativitas, diklat teknis substantif, pengawas madrasah.

\section{ABSTRACT}

The creativity of madrasah supervisors (at MI, MTs and MA levels) is often a problem with the activities of academic supervision and managerial supervision, especially in the preparation of instruments used as a means of supervision. The purpose of writing this paper is to describe the effect of training on increasing the creativity of madrasah supervisors. The methodology and data analysis are to take the participants setting of Diklat Teknis Substantif Pengawas Madrasah Madya Angkatan I - Pusdiklat Tenaga Teknis Pendidikan dan Keagamaan on May 31 - June 10, 2017. The data obtained from 30 respondents class I training participants. The results of data analysis before given the core material Diklat value obtained that is 64.0 and after given the core material diklat an increase in the value of 73.7. 
There is an increase in creativity value of 9.7 after being given core training materials. Thus, it can be concluded that Diklat Teknis Substantif Pengawas Madrasah Madya increases the creativity of madrasah supervisors.

Keywords: reativity, substantive training, madrasah supervisors

\section{PENDAHULUAN}

mulai diharapkan madrasah, pengawas madrasah pada setiap kegiatan kependidikan belum optimal berperan. Seakan peran pengawas madrasah antara ada dan tiada. Padahal peran pengawas madrasah tidaklah kecil dalam membina para guru madrasah (baik padajenjang satuan pendidikan madrasah ibtidaiyah, madrasah tsanawiyah, maupun madrasah aliyah), staf pendidikan dan memajukan pendidikan. Dalam Undang-Undang Sistem Pendidikan Nasional, keberadaan pengawas tidak termaktub secara eksplisit dan hanya ditulis sebagai tenaga kependidikan. Setelah muncul Peraturan Menteri Pendidikan Nasional Nomor 12 Tahun 2007 tentang Standar Pengawas Sekolah/Madrasah maka kedudukan, peran, fungsi dan kompetensi pengawas sekolah/madrasah sangat jelas. Dikuatkan dengan hadirnya Peraturan Menteri Agama Republik Indonesia Nomor 2 Tahun 2012 tentang Pengawas Madrasah dan Pengawas Pendidikan Agama Islam pada Sekolah; pada Bab III
Tanggung Jawab dan Wewenang pasal 5: (3) Pengawas Madrasah sebagaimana dimaksud pada ayat (1) berwenang: a. memberikan masukan, saran, dan bimbingan dalam penyusunan, pelaksanaan, dan evaluasi program pendidikan dan/atau pembelajaran kepada Kepala madrasah, Kepala Kantor Kementerian Agama Kabupaten/ Kota atau Kepala Kantor Wilayah Kementerian Agama Provinsi; b. memantau dan menilai kinerja Kepala Madrasah serta merumuskan saran tindak lanjut yang diperlukan; c. melakukan pembinaan terhadap pendidik dan tenaga kependidikan di madrasah; dan d. memberikan perimbangan dalam penilaian pelaksanaan tugas, dan penempatan Kepala Madrasah serta guru kepada Kepala Kantor Kementerian Agama Kabupaten/ Kota.

Dengan kata lain, tugas pengawas madrasah adalah memberikan bimbingan, penilaian dan pembinaan terhadap para guru madrasah di bawah wewenang dan tanggung jawabnya. Kegiatan kepengawasan tersebut memberikan dampak yang tidak sedikit terhadap kemajuan dan peningkatan profesionalisme 
guru madrasah khususnya dan dunia pendidikan pada umumnya. Pengawas madrasah yang berwatak "supervisor profesional" tidak sekedar merencanakan program (planing), juga bukan sekedar mengatur dan membagi-bagikan pekerjaan kepada bawahan (organizing) kepala madrasah dan guru, bukan juga sekedar pandai menggerakkan bawahan untuk bekerja maksimal (actuating), tetapi ia juga ahli dalam melakukan pengawasan (controlling atau supervition), objektif dan bijak dalam memberikan penilaian (evaluating).

Pekerjaan pengawas madrasah yang sudah terprogram, kemudian diaplikasikan secara cerdas dan baik, serta ditopang dengan evaluasi yang objektif, niscaya akan membawa hasil pekerjaan lebih optimal. Begitu pula kegiatan supervisi (pengawasan) dimanapun jenjang pendidikannya, harus dilakukan seorang pengawas madrasah yang memiliki kompetensi. Pengawas madrasah yang tidak memiliki wawasan dan kompetensi memadai sulit beradaptasi dengan pekerjaannya. Mengapa? Karena, di tahun 1990an masih ada pengangkatan pengawas madrasah yang bertugas tidak melalui jenjang jabatan guru atau kepala madrasah/sekolah. Artinya, masih ada mantan pejabat struktural, seperti Kepala Kantor Kementerian Agama Kabupaten/ Kota dan Kepala Kantor Urusan
Agama Kecamatan beralih profesi menjadi pengawas madrasah atau pengawas pendidikan agama Islam pada sekolah. Hal itu mereka lakukan untuk memperpanjang masa pensiun.

Sementara di tahun 2000an atau sejak keluarnya Peraturan Menteri Pendidikan Nasional Republik Indonesia Nomor 12 Tahun 2007 tentang Standar Pengawas Sekolah/Madrasah maka alur perekrutan pengawas sekolah/ madrasah mulai teratur, yaitu jenjang karier pengawas dimulai dari guru lalu kepala sekolah/ madrasah kemudian pengawas sekolah/madrasah. Sedangkan Kementerian Agama menyambut regulasi pengawas sekolah/ madrasah tersebut dengan mengeluarkan Peraturan Menteri Agama (PMA) Nomor 2 Tahun 2012 tentang Pengawas Madrasah dan Pengawas Pendidikan Agama Islam pada Sekolah. Peraturan Menteri Agama Nomor 2 Tahun 2012 tersebut sebagian isinya mengadopsi Peraturan Menteri Pendidikan Nasional Republik Indonesia Nomor 12 Tahun 2007 tentang Standar Pengawas Sekolah/Madrasah. Di dalam PMA 2 Tahun 2012 mulai gamblang tugas, fungsi. dan wewenang pengawas madrasah.

Sedangkan tugas dan fungsi pengawas dalam Peraturan Menteri Pendayagunaan Aparatur Negara dan Reformasi Birokrasi 
Republik Indonesia Peraturan Nomor 21 Tahun 2010 tentang Jabatan Fungsional Pengawas Sekolah Bab II Pasal 5 tentang Tugas pokok Pengawas Sekolah adalah melaksanakan tugas pengawasan akademik dan manajerial pada satuan pendidikan yang meliputi penyusunan program pengawasan, pelaksanaan pembinaan, pemantauan pelaksanaan 8 (delapan) Standar Nasional Pendidikan, penilaian, pembimbingan dan pelatihan professional guru, evaluasi hasil pelaksanaan program pengawasan, dan pelaksanaan tugas kepengawasan di daerah khusus.

\section{Jika pengawas madrasah tidak memiliki kompetensi atau menguasai tugas-tugas} kepengawasan ketika melakukan supervisi kelas, observasi madrasah, dan pembinaan terhadap guru madrasah lainnya, dikhawatirkan citra pengawas madrasah akan terpuruk terus. Sementara itu supervisi akademik terhadap guru terbatas pada administrasi guru (pembuatan perencanaan/ program pengajaran, pembuatan silabus mata pelajaran, RPP, buku kehadiran siswa, buku pengayaanremedial), dan sebagainya. Untuk mengetahui keakuratan perangkat pembelajaran tersebut, pengawas melakukan supervisi kelas dan menilai bagaimana guru mengajar. Bila seorang mantan struktural (mantan Kepala Kantor
Kementerian Agama atau Kepala Kantor Urusan Agama, misalnya) melakukan supervisi akademik di kelas, bukan tidak mungkin akan mengalami kendala. Disamping itu masih terdengar keluhan guru (terutama saat kegiatan diklat guru di Pusdiklat Tenaga Teknis Pendidikan dan Keagamaan), bahwa pengawas madrasah belum optimal menjalankan tugas kepengawasannya di madrasah. Hal itu dikarenakan pengawas madrasah kurang kreatif dan inovatif dalam bertugas. Bahkan ada keluhan guru-guru madrasah (terutama guru pendidikan umum) yang telah bertugas lebih 10 (sepuluh) tahun, namun belum pernah disupervisi oleh pengawas madrasah. Memang banyak faktor penyebab pengawas madrasah tidak menjalankan tugas kepengawasannya secara optimal.

Sementara itu secara ideal seorang pengawas diharapkan memiliki citra dan wibawa akademik di atas guru dan kepala madrasah, sehingga kehadirannya di madrasah dapat melaksanakan fungsi pengawasan akademik dan manajerial sebagaimana mestinya. Karena kepada pengawaslah guru dan kepala madrasah akan mengkonsultasikan berbagai permasalahan yang dihadapi di madrasah, baik sebagai pribadi maupun sebagai pendidik professional. Tentunya beragam persoalan yang dikemukakan memerlukan pemikiran yang 
berbeda dan cara penyelesaian yang tepat, sehingga dicapai hasil yang diharapkan. Implikasinya seorang pengawas madrasah harus memahami dan menguasai metode, teknik dan konsep kreativitas serta belajar bersikap kreatif agar dapat memandang permasalahan secara komprehensif dan merekomendasi solusi yang paling tepat. Berdasarkan hal itulah penulis memilih kajian "Peningkatan Kreativitas Pengawas Madrasah Melalui Diklat". Pertanyaannya adalah apakah Diklat Teknis Substantif bagi Pengawas Madrasah Madya dapat meningkatkan kreativitas peserta diklat pengawas madrasah?

Makalah ini mengkaji
tentang upaya peningkatan
kreativitas pengawas madrasah
dengan aktivitas diklat. Pada
dasarnya, diklat substantif bagi
pengawas madrasah madya
untuk meningkatkan kompetensi,
terutama dalam tugas pokok
pengawas, seperti supervisi
akademik dan supervisi manajerial.
Dengan pemberian materi tugas
pokok kepengawasan diharapkan
pengawas madrasah madya
memiliki peningkatan kompetensi.

Penelitian tentang kreativitas sebelumnya telah banyak dilakukan, karena ranah krativitas sangat menarik untuk dikaji lebih dalam. Tentu saja penelitian pendahulu mengambil objek sasaran yang berbeda. Artinya, objek sasaran bisa pegawai negeri sipil (PNS) di salah satu instansi pemerintahan tertentu, guru, kepala sekolah, pengawas dan warga masyarakat lainnya.

Pada kesempatan ini, penulis mengutip St. Hasniyati Gani Ali dalam Disertasinya yang berjudul Implementasi Profesionalisme Pengawas dalam Meningkatkan Kreativitas Guru Pendidikan Agama Islam (Studi tentang Pengelolaan Pembelajaran pada Madrasah Aliyah Negeri di Provinsi Sulawesi Tenggara). Disertasi ini mengungkap profesionalisme pengawas dalam meningkatkan kreativitas guru mengelola pembelajaran, mendeskripsikan proses penerapan profesionalisme pengawas dalam meningkatkan kreativitas guru, merumuskan faktor pendukung dan hambatan yang ditemui serta menemukan, menganalisis upaya mengatasi hambatan implementasi profesionalisme pengawas guna meningkatkan kreativitas guru PAI dalam mengelola pembelajaran. Pokok permasalahan adalah bagaimana implementasi profesionalisme pengawas guna meningkatkan kreativitas guru pendididikna agama Islam (Studi tentang pengelolaan pembelajaran pada MAN di Provinsi Sulawesi Tenggara). Penelitian tersebut adalah penelitian lapangan (field Research) dalam menghimpun data lapangan peneliti menggunakan metode observasi, wawancara, 
dan dokumentasi. Kemudian masalah ini dilihat dari pendekatan multi disipliner, yaitu pendekatan pedagogik, psikologis, sosiologis, teologis normatif serta menejemen, dengan analisis data kualitatif deskriptif yakni menggambarkan secara sistimatis, faktual dan akurat, kemudian data tersebut disimpulkan secara induktif.

Hasil penelitian menunjukkan bahwa dalam penerapan profesionalisme pengawas dalam meningkatkan kreativitas guru PAI telah terlaksana meskipun belum maksimal. Indikatornya adalah, dalam melaksanakan pembinaan kepada guru agama pada bidang perencanaan hanya 6 orang $(60 \%)$, pada bidang proses pembelajaran hanya 7 orang $(70 \%)$, penggunaan media 4 orang (40\%), pada bidang evaluasi hanya 4 orang (40\%) dari 10 orang pengawas yang diamati, sehingga berdampak pada kreativitas guru mengelola pembelajaran.

Pada penelitian lain, penulis mengutip hasil penelitian Deasy Amallia Rani yang diberi judul "Hubungan antara Iklim Organisasi dengan Peluang untuk Berkreasi pada Karyawan Desain PT. Batik Danar Hadi Surakarta".

Menurut Deasy, peluang untuk berkreasi sangat penting dimiliki oleh seluruh karyawan desain untuk mencapai kinerja dan produktivitas yang memuaskan. Jika karyawan memiliki peluang berkreasi yang baik, maka akan dapat menghasilkan gagasan-gagasan yang lebih menguntungkan bagi perusahaan. Jika perusahaan menginginkan karyawan-karyawan kreatif yang selalu terdorong untuk meningkatkan mutu produknya, maka yang perlu diusahakan adalah menciptakan iklim organisasi yang menghargai kreativitas, memberi kesempatan, baik waktu, sarana dan prasarana serta insentif kepada karyawan untuk memikirkan, merancang, meneliti, dan mengembangkan produk-produk baru yang lebih memuaskan. Penelitian ini bertujuan untuk menguji secara empirik hubungan antara iklim organisasi dengan kreativitas pada karyawan desain PT. Batik Danar Hadi Surakarta.

Subjek dalam penelitian ini adalah karyawan tetap bagian desain motif, desain bordir dan desain house hold.

Dalam penelitian tersebut, peneliti menggunakan pendekatan tes ulang (test retest), dengan jumlah populasi 40 orang karyawan desain, sehingga peneliti menggunakan seluruh subjek dalam penelitian, atau dapat dikatakan sebagai teknik studi populasi. Metode pengumpulan data menggunakan dua buah skala psikologi, yaitu skala peluang untuk berkreasi yang disusun berdasarkan aspek kreativitas menurut Munandar (1999: 21-22), 
dengan jumlah item sebanyak 27 item, dan Skala Iklim Organisasi yang disusun berdasarkan aspekaspek dari Kolb dan Rubin (1984, h.343), dengan jumlah item sebanyak 43 item. Analisis data dilakukan dengan metode analisis regresi sederhana dengan bantuan teknik Statistical Package for Social Science (SPSS) versi 12.0. Hasil analisis data menghasilkan koefisien korelasi $r x y=0,611$ dengan $p=0,000(p<0,05)$, yang berarti ada hubungan positif antara peluang untuk berkreasi dan iklim organisasi pada karyawan desain PT. Batik Danar Hadi Surakarta. Semakin positif iklim organisasi, maka semakin tinggi pula peluang untuk berkreasi pada karyawan. Efektivitas regresi penelitian ini sebesar 37,4\%, artinya peluang untuk berkreasi karyawan desain sebesar 37,4\% ditentukan oleh iklim organisasi. Peluang untuk berkreasi karyawan dan iklim organisasi berada pada kategori sedang.

Kedua penelitian di atas menganggap bahwa kreativitas itu penting dalam kehidupan bermasyarakat, baik di lingkungan organisasi kerja maupun di luar dunia kerja. Perbedaannya adalah pada objek sasaran kajian atau penelitian. Penulis mengkaji objek sasaran peserta diklat pengawas, St. Hasniyati Gani Ali mengambil objek sasaran pengawas dan guru; sedangkan Deasy Amallia Rani mengambil objek sasaran karyawan PT Batik Danar Hadi Surakarta.

Ketika melihat suatu karya seseorang yang dipamerkan atau dibangun di suatu tempat, sebut saja busana yang dikenakan seorang pragawati elegan, bangunan patung kuda di Jalan M.H. Thamrin, muncul komentar kita "sungguh indah dan detail pembuatannya", atau ketika melihat kerajinan tangan atau cara mengolah sampah yang kreatif "kenapa tidak terpikir sampai ke sana ya?", yang ada pada benak kita pada saat menyelesaikan kegiatan. Komentar seperti tadi dan mungkin disertai kekaguman juga pernah terlontar pada saat kita melihat sebuah hasil karya seseorang, tanggapan atau ide yang disampaikan seseorang pada suatu forum tertentu.

Mengapa orang dapat berpikir atau dapat menghasilkan suatu karya yang tidak terpikir oleh kita? Atau mengapa orang mampu menyelesaikan persoalan dengan lebih cepat dengan cara yang unik dan mencapai hasil yang baik? Hal tersebut dapat terjadi karena seseorang memiliki keterampilan berpikir memecahkan masalah secara kreatif.

Apakahseseorang dapatbelajar mengembangkan keterampilan berpikir memecahkan masalah? $\mathrm{Ya}$, setiap orang dapat belajar untuk mengembangkan berpikir kreatif dan mengintegrasikan 
kemampuan tersebut dengan keterampilan-keterampilan berpikir tingkat tinggi lain, sehingga mampu menyelesaikan berbagai permasalahan. Belajar mengeksplorasi mimpi dan berbagai kemungkinan dengan mengembangkan kepekaan terhadap petualangan, kejutan, kenyamanan dan kesenangan sehingga memfasilitasi ide-ide baru dan pemecahan masalah secara inovatif sesuai kebutuhan. Ide-ide tersebut berbeda dan menunjukkan kualitas yang tinggi.

Saat sekarang, perubahan kehidupan guru madrasah berlangsung sangat cepat dan kompleks dengan berbagai permasalahan dan tantangan. Setiap guru madrasah baik guru mata pelajaran umum atau mata pelajaran pendidikan agama Islam (PAI) dituntut untuk fleksibel, kritis dan terampil berpikir kreatif sehingga mampu menangani permasalahan dan menemukan solusi yang melibatkan lingkungan sosial maupun fisik. Hari Kamis, 7 Juni 2017 penulis sempat menjumpai ibu Fery, mantan guru agama Islam (PAI) di salah satu SMK Negeri 39 Jakarta yang kini telah beralih fungsi sebagai pengawas madrasah di Jakarta Pusat. Beliau bertutur tentang kemampuannya mengoperasikan multimedia sejak menjadi guru. Saat menjadi guru di SMK Negeri 39 hanya ibu Fery yang mampu menggunakan multimedia pemberian Dinas Pendidikan DKI
Jakarta. Dengan demikian, saat menjadi pengawas madrasah di Jakarta Pusat pemanfaatan multimedia adalah bukan hal sulit untuk digunakan, terutama untuk mengolah data hasil pengawasan.

Tak lepas dari kreativitas memanfaatan multimedia dan kreativitas dalam menjalankan tugas kepengawasan, pahamkah kita tentang hakikat kreativitas itu?

Jadi, apa itu kreativitas? Bagaimana mengembangkan keterampilan berpikir kreatif? Bagaimana memecahkan masalah secara kreatif, dan bagaimana kita mampu memfasilitasi orang lain untuk berpikir kreatif dan bertindak kreatif?

Menurut Lumsdaine (1995: 14) kreativitas adalah mempergunakan imaginasi dan berbagai kemungkinan yang diperoleh dari interaksi dengan ide atau gagasan orang lain dan lingkungan untuk membuat koneksi dan hasil yang baru serta bermakna. Artinya, mengembangkan pemikiran alternatif atau kemungkinan dengan berbagai cara sehingga mampu melihat sesuatu dari berbagai sudut pandang dalam interaksi individu dengan lingkungan sehingga diperoleh cara-cara baru untuk mencapai tujuan yang lebih bermakna.

Menurut Conny R Semiawan (2009: 44), kreativitas adalah modifikasi sesuatu yang sudah ada 
menjadi konsep baru. Dengan kata lain, terdapat dua konsep lama yang dikombinasikan menjadi suatu konsep baru. Sedangkan menurut Utami Munandar (2009: 12), bahwa kreativitas adalah hasil interaksi antara individu dan lingkungannya, kemampuan untuk membuat kombinasi baru, berdasarkan data, informasi, atau unsur-unsur yang sudah ada atau dikenal sebelumnya, yaitu semua pengalaman dan pengetahuan yang telah diperoleh seseorang selama hidupnya baik itu di lingkungan sekolah, keluarga, maupun dari lingkungan masyarakat.

Pendapat lain, Barron yang dikutip dari Ngalimun dkk (2013: 44) kreativitas didefinisikan sebagai kemampuan untuk menciptakan sesuatu yang baru. Guilford yang dikutip dari Ngalimun dkk (2013: 44) menyatakan bahwa kreativitas mengacu pada kemamampuan yang menandai seorang kreatif. Rogers (Utami Munandar, 1992: 51) mendifinisikan kreativitas sebagai proses munculnya hasil-hasil baru ke dalam tindakan. Hasil-hasil baru itu muncul dari sifat-sifat individu yang unik yang berinteraksi dengan individu lain, pengalaman, maupun keadaan hidupnya.

Demikian juga Dreavdahl (Hurlock, 1978: 325) yang dikutip dari Ngalimun dkk., (2013:45) mendefinsikan kreativitas sebagai kemampuan untuk memproduksi komposisi dan gagasan-gagasan baru yang dapat berwujud kreativitas imanjenatif atau sintesis yang mungkin melibatkan pembentukan pola-pola baru dan kombinasi dari pengalaman masa lalu yang dihubungkan dengan yang sudah ada pada situasi sekarang. Kreativitas juga tidak selalu menghasilkan sesuatu yang dapat diamati dan dinilai. Menurut Jawwad (2004) dikutip dari Kemendikbud (2011: 28) kreativitas adalah kemampuan berpikir untuk meraih hasil-hasil yang variatif dan baru, serta memungkinkan untuk diaplikasikan, baik dalam bidang keilmuan, keolahragaan, kesusastraan, maupun bidang kehidupan lain yang melimpah.

Menurut Chandra (1994) dikutip dariKemendikbud (2011:28) kreativitas merupakan kemampuan mental dan berbagai jenis keterampilan khas manusia yang dapat melahirkan pengungkapan unik, berbeda, orisinal, sama sekali baru, indah, efisien, tepat sasaran dan tepat guna.

Tak lepas dari beberapa definisi di atas, pernahkah kita merasa kosong pikiran atau merasa tidak berdaya karena tidak dapat berbuat apa-apa? Kreativitas merupakan aktivitas dinamis dalam diri kita yang melibatkan proses mental pada alam sadar maupun di bawah sadar. Pada saat kita mengatakan dalam alam bawah sadar tidak mampu melakukan maka secara 
sadar kita menjadi tidak mampu melakukan. Sebaliknya pada saat kita menunjukkan kemampuan kita melakukan sesuatu secara sadar maka akan tumbuh keberhargaan diri pada alam bawah sadar dan tertampilkan kembali dalam sikap percaya diri.

Kreativitas melibatkan keseluruhan otak. Seseorang akan bertindak kreatif manakala mempergunakan potensi otak dengan optimal. Mempergunakan kedua belahan otak, otak kiri dan otak kanan. Otak kiriyang mengatur kemampuan logika dan otak kanan yang mengatur humanistis. Implikasinya setiap persoalan yang datang dilihat tidak hanya dari kacamata logika tetapi berbagai dimensi yang menyertainya. Contoh sederhana, jika ditanyakan kepada kita apa guna sapu lidi? Jawaban secara logika adalah alat untuk menyapu lantai atau menyapu halaman rumah sesuai dengan fungsi utama. Mari kita menggunakan otak kanan, dengan bentuk dan kondisinya sapu dapat dipergunakan untuk menggiring ayam atau bebek; atau satuan lidinya dapat digunakan untuk menyalakan kompor minyak tanah; jika tak ada tusuk sate maka lidi pun dapat dimanfaat untuk tusuk sate, tentunya lidi tersebut harus diraut dan dibersihkan dulu.

Kunci kreativitas adalah kemampuan menilai permasalahan dari berbagai sudut pandang sehingga menjadi solusi yang lebih baik. Sudut pandang yang berbeda akan menstimulasi beragam ide dan mengembangkan struktur kognitif baru. Contoh seorang anak mungkin dipandang bodoh oleh guru manakala memperoleh nilai 2 (dua) pada saat ulangan Matematika. Pertanyaannya mengapa? Hal itu akan merujuk kepada berbagai kemungkinan kondisi anak. Apakah anak tidak mengalami gangguan fisik yang menghambat penerimaan materi belajar? Apakah anak tidak memiliki alat penunjang belajar? Seperti buku, media penunjang dan sebagainya. Ada berapa anak yang memperoleh nilai 2 (dua)? Pada pelajaran lain berapa nilai yang dapat diperoleh? Itu beberapa pertanyaan yang dapat kita ajukan jika kita melihat dari berbagai sudut pandang yang berbeda. Jawaban berbeda dari beragam pertanyaan akan memberikan gambaran masalah utama yang dihadapi anak, sehingga memfasilitasi kita untuk menetapkan solusi bantuan yang paling mungkin dilakukan. Kreativitas mengekspresikan kualitas solusi penyelesaian masalah.

Pada bagian lain Mamat Supriatna (2006) menjelaskan kreativitas adalah kemampuan cipta, karsa, dan karya seseorang untuk dapat menciptakan sesuatu yang baru. Sesuatu yang baru itu dapat ditemukan dengan menghubungkan atau 
menggabungkan sesuatu yang sudah ada. Kreativitas adalah bakat yang dimiliki oleh setiap orang yang dapat dikembangkan dengan pelatihan dan aplikasi yang tepat. Banyak studi telah dilakukan tentang perilaku kreatif dari para musisi, ilmuwan besar, arsitek, pujangga, dan pelukis. Hasilnya adalah bahwa proses kreativitasnya sama, baik kreativitas itu terpusat pada pemecahan masalah sehari-hari, atau penemuan ilmiah tingkat tinggi.

Menurut Need Hermann dalam Forum Guru Nusantara (2016:1) pada dasarnya jika kita melibatkan secara penuh pikiran yang dimiliki sehingga membangkitkan ide dan kenyataan tentang sesuatu yang diinginkan atau ingin dicapai kita memfasilitasi berkembangnya kreativitas. Kekuatan pikiran membayangkan berbagai kemungkinan dalam mencapai apa yang diinginkan dalam koridor norma-norma yang dapat ditoleransi. Artinya, orang kreatif tahu apa yang diinginkan dan dapat menetapkan tujuan berperilaku.

Melakukan berbagai cara yang beragam untuk melakukan suatu aktivitas, refleksi apakah memberi cara yang lebih efektif, efisien, dan produktif? Perhatikan reaksi atau komentar orang lain terhadap penampilan/kinerja/unjuk kerja kita, apakah menunjukkan apresiasi yang positif dan kepuasan? Hal tersebut merupakan indikator sederhana apakah kita kreatif atau tidak. Jika kita dan orang lain berusaha kreatif, maka kita akan lebih kreatif. Mengembangkan perilaku kreatif dimulai dengan mengembangkan kemampuan berpikir kreatif.

Dalam Peraturan Menteri Agamatentang Pengawas Madrasah dan Pengawas Pendidikan Agama Islam pada Sekolah, disebutkan bahwa pengawas madrasah adalah guru Pegawai Negeri Sipil yang diangkat dalam jabatan fungsional pengawas satuan pendidikan yang tugas, tanggung jawab, dan wewenangnya melakukan pengawasan akademik dan manajerial pada madrasah.

Tercapainya suatu tujuan pendidikan di level manapun, sebagian besar tergantung pada pelaksanaan programsecararelevan dan realistis, sesuai dengan materi program yang telah direncanakan. Termasuk di dalamnya adalah program pengawasan (bimbingan dan pembinaan) yang relevan dan realistis pada pelaksanaan pendidikan di sekolah/madrasah.

Sementara itu, secara garis besar supervisi akademik terhadap guru, khususnya guru mata pelajaran agama Islam (PAI) dan mata pelajaran umum terbatas pada administrasi guru, seperti pembuatan perencanaan/ program pengajaran, pembuatan silabus mata pelajaran, RPP, buku 
kehadiran siswa, buku pengayaanremedial, dan sebagainya. Secara ideal, seorang pengawas madrasah diharapkan memiliki citra dan wibawa akademik di atas guru dan kepala sekolah sehingga kehadirannya di sekolah dapat melaksanakan fungsi pengawasan akademik dan manajerial sebagaimana mestinya. Kepada pengawaslah guru dan kepala sekolah/madrasah akan mengkonsultasikan berbagai permasalahan yang dihadapi di sekolah baik permasalahan pengajaran dan pendidikan maupun masalah pribadi. Beragam persoalan guru mata pelajaran umum dan PAI di madrasah yang dikemukakan memerlukan pemikiran yang berbeda dan cara penyelesaian yang tepat sehingga dicapai hasil yang diharapkan. Implikasinya seorang pengawas madrasah memahami konsep kreativitas dan belajar bersikap kreatif agar dapat memandang permasalahan secara komprehensif dan merekomendasi solusi yang paling tepat.

Manusia adalah makhluk yang diberi kemampuan untuk menyesuaikan diri dengan berbagai situasi dan tantangan kehidupan. Perubahan yang terusmenerus secara global menuntut manusia beradaptasi dengan cepat terhadap berbagai situasi dan kondisi yang seringkali tidak dapat diprediksi. Tingkat keragaman dan kedalaman permasalahan sangat tinggi karena berada dalam koridor konteks yang kompleks. Manusia dituntut memikirkan dan bertindak dengan berbagai cara untuk dapat menguraikan kompleksitas tantangan dan memikirkan berbagai alternatif tindakan yang dapat dilakukan. Untuk itulah, manusia membutuhkan kreativitas.

Kemampuan beradaptasi dipengaruhi oleh bagaimana manusia memandang suatu permasalahan. Apakah permasalahan dianggap sesuatu yang menyulitkan, merugikan dan mengancam diri atau permasalahan dipandang sebagai tantangan yang membuat diri menjadi lebih tahu, terampil atau mampu bertindak lebih baik. Orientasi memandang suatu persoalan merupakan kunci awal seseorang memiliki kreativitas. Pandangan positif memfasilitasi berkembangnya imajinasi tentang kondisi yang harus dihadapi sehingga persoalan dapat dilihat secara komprehensif. Imajinasi berbagai pengalaman sendiri dan atau orang lain yang dimaknai sebagai proses belajar memberi peluang pada inidividu melihat berbagai kemungkinan atau alternatif tindakan yang dapat dilakukan.

Pola asuh orang tua maupun pendidikan di sekolah membuat banyak orang di Indonesia tidak dapat menunjukkan kreativitas. Orang tua bertindak atas dasar aturan-aturan baku yang tidak 
memfasilitasi adanya celah untuk berubah. Dengan berbagai alasan dari mulai tabu, pamali, kata orang tua, hingga menjadi instruksi yang berharga mati. Sebuah pelanggaran yang dilakukan anak pada aturan tersebut membuat anak dicap nakal oleh orang tua. Contoh, anak usia taman kanakkanak berada pada masa senang mencoret-coret apapun menjadi gambar yang belum jelas. Orang tua menganggap nakal karena mengotori tembok atau meja. Padahal jika orang tua memfasilitasi ruangan dengan menempel kertas roti setinggi badan anak di tembok yang diganti setiap waktu setelah penuh coretan yang dibuat anak pada kertas tersebut membuat keterampilan motorik halus tangan dan jari mencapai kematangan. Hal penting lain yang diperoleh anak dari kegiatan tersebut adalah berkembangnya imajinasi untuk mencoretkan apapun sesuai bentuk yang ada pada angannya.

Variasi dan keragaman harus dipandang sebagai potensi yang membuat kehidupan menjadi menarik dan berwarna. Hal yang tidak menyenangkan jika semua orang berpikir dan bertindak seragam. Kehidupan menjadi mati karena orang akan bergerak dan bertindak dalam rutinitas yang sistematik terkontrol. Manusia menjadi tidak berbeda dengan robot.

Kaitannya dengan kreativitas maka pengawas madrasah harus memiliki 6 (enam) kompetensi, yaitu kompetensi kepribadian dan sosial, supervisi akademik, supervisi manajerial, monitoring dan evaluasi, penelitian dan pengembangan profesi, seperti yang tertuang dalam Peraturan Mendiknas No. 12 Tahun 2007 tentang Standar Pengawas Sekolah/Madrasah.

Pengawas madrasah yang kreatif harus memahami keenam kompetensi pengawas. Bersikap kreatif membawa dampak positif pada diri sendiri dan lingkungan sekitar. Pada diri sendiri mendorong aktulisasi potensi yang dimiliki. Bagi orang lain dalam hal ini para guru mata pelajaran umum dan PAI memberikan kepuasaan karena tindakanyang dilakukan pada waktu yang lebih cepat dan memberi hasil yang lebih tepat. Apalagi telah banyak guru mata pelajaran umum dan PAI di madrasah yang telah memiliki pendidikan S2 dan S3 atau berwawasan teknologi dan informasi terkini.

Seorang pengawas madrasah yang kreatif memiliki karakteristik sebagai berikut.

1. Cenderung melihat suatu persoalan sebagai tantangan untuk menunjukkan kemampuan diri.

2. Cenderung memikirkan alternatif solusi/tindakan yang tidak dilakukan oleh orang orang pada umumnya atau 
bukan sesuatu yang sudah biasa dilakukan.

3. Tidak takut untuk mencoba hal-hal baru.

4. Mau belajar mempergunakan cara, teknik, dan peralatan baru.

5. Tidak takut dicemoohkan oleh orang lain karena berbeda dari kebiasaan.

6. Tidak malu bertanya berbagai informasi sesuatu hal yang dianggap menarik.

7. Tidak cepat puas terhadap hasil yang diperoleh.

8. Toleran terhadap kegagalan dan frustasi.

9. Memikirkan apa yang mungkin dapat dilakukan atau dikerjakan dari suatu kondisi, keadaan atau benda.

10. Melakukan berbagai cara yang mungkin dilakukan dengan tetap berdasar pada integrasi kejujuran, menjujung sistem nilai, bertujuan positif.

11. Tindakan yang dilakukan efektif, efisien, dan produktif.

Diklat Teknis Substantif Pengawas Madrasah Madya merupakan pendidikan dan latihan singkat yang diselenggarakan oleh Pusdiklat Tenaga Teknis Pendidikan dan Keagamaan. Meningkat kreativitas adalah bertambah kompetensi dan kemampuan dalam melakukan kegiatan. Dengan demikian, pengawas madrasah yang meningkat kreativitasnya akan bertambah komptensinya dalam melakukan kegiatan. Dalam materi inti kurikulum dan silabus Diklat Teknis Substantif Pengawas Madrasah Madya termuat: Manajemen Berbasis Madrasah, (2) Analisis Standar Pendidikan, (3) Teknik Supervisi Manajerial dan Penyusunan Instrumen, (4) Teknik Supervisi Akademik dan Penyusunan Instrumen, (5) Penelitian Tindakan Kepengawasan (PTKp) (6) Penghitungan Angka Kredit Pengawas, (7) Pemanfaatan Teknologi Informasidan Komunikasi (TIK), dan (8) Evaluasi Pendidikan. Materi-materi yang ditawarkan dalam Diklat Teknis Substantif Pengawas Madrasah Madya di atas diharapkan mampu memotivasi dan memberi pencerahan terhadap kompetensi pengawas madrasah. Karena dalam kegiatan diklat diberikan teori, praktek, diskusi atau simulasi. Dengan demikian, seusai diklat para pengawas madrasah bertambah kreatif dalam bekerja dan mampu memberikan bimbingan serta menemukan solusi permasalahan yang dihadapi para guru madrasah di lapangan.

\section{METODE PENELITIAN}

Karya tulis ini mengambil setting dan responden di Pusdiklat Tenaga teknis Pendidikan dan Keagamaan. Adapun pengambilan data dilakukan terhadap peserta Diklat Teknis Substantif Pengawas Madrasah Madya Angkatan I pada 
tanggal 31 Mei sampai dengan 10 Juni 2017. Karya tulis ini mengkaji data dari 30 (tiga puluh) orang responden peserta Diklat.

\section{HASIL DAN PEMBAHASAN}

\section{Hasil}

Prosedur penulisan karya tulis ini dimulai dari perencanaan, pelaksanaan, observasi dan penyelesaian penyusunan karya tulis. Penyusunan sketsa singkat tentang ide dasar merupakan awal dari penyusunan karya tulis ini. Setelah itu penyusunan latar belakang, dilakukan pengumpulan data teori yang selanjutnya dilakukan observasi dalam rangka pengambilan data, dengan menggunakan skala 0 - 100 .

Pengambilan data tiap item perilaku dihitung secara rata-rata dari 30 (tiga puluh) responden, baik data sebelum maupun setelah peserta mengikuti pembelajaran diklat. Analisis deskriptif dari data kreativitas dapat dilihat hasilnya berikut ini.

\section{Tabel 1: Data Perilaku Pengawas Kreativitas}

\begin{tabular}{|c|c|c|}
\hline No. & Perilaku Pengawas Kreatif & $\begin{array}{c}\text { Hasil sebelum } \\
\text { diberi materi inti }\end{array}$ \\
\hline 1. & $\begin{array}{l}\text { Memiliki gagasan-gagasan baru dan dikombinasikan dari } \\
\text { pengalaman masa lalu yang dihubungkan dengan situasi } \\
\text { sekarang }\end{array}$ & 60 \\
\hline 2. & $\begin{array}{l}\text { Melihat suatu persoalan sebagai tantangan untuk } \\
\text { menunjukkan kemampuan diri }\end{array}$ & 65 \\
\hline 3. & $\begin{array}{l}\text { Memikirkan alternatif solusi/tindakan yang tidak dilakukan } \\
\text { oleh orang-orang pada umumnya }\end{array}$ & 61 \\
\hline 4. & Tidak takut untuk mencoba hal-hal baru & 65 \\
\hline 5. & $\begin{array}{l}\text { Mau belajar mempergunakan cara, teknik dan peralatan } \\
\text { baru }\end{array}$ & 67 \\
\hline 5. & $\begin{array}{l}\text { Tidak takut dicemoohkan oleh orang lain karena berbeda } \\
\text { dari kebiasaan }\end{array}$ & 65 \\
\hline 6. & $\begin{array}{l}\text { Tidak malu bertanya berbagai informasi pada sesuatu hal } \\
\text { yang dianggap menarik }\end{array}$ & 60 \\
\hline 7. & Toleran terhadap kegagalan dan frustasi & 67 \\
\hline 8. & Tidak cepat puas terhadap hasil yang diperoleh & 60 \\
\hline 9. & $\begin{array}{l}\text { Melakukan suatu aktivitas secara lebih efektif, efisien, dan } \\
\text { produktif }\end{array}$ & 66 \\
\hline 10. & $\begin{array}{l}\text { Melakukan sesuatu berdasar pada integrasi kejujuran, } \\
\text { menjujung sistem nilai, bertujuan positif }\end{array}$ & 64 \\
\hline & Total rata-rata & $640 / 10=64,0$ \\
\hline
\end{tabular}


Tabel 2: Data Perilaku Pengawas Kreativitas

\begin{tabular}{|c|l|c|}
\hline No. & \multicolumn{1}{|c|}{ Perilaku Pengawas Kreatif } & $\begin{array}{c}\text { Hasil sesudah } \\
\text { diberi materi inti }\end{array}$ \\
\hline 1. & $\begin{array}{l}\text { Memiliki gagasan-gagasan baru dan dikombinasikan } \\
\text { dari pengalaman masa lalu yang dihubungkan dengan } \\
\text { situasi sekarang }\end{array}$ & 70 \\
\hline 2. & $\begin{array}{l}\text { Melihat suatu persoalan sebagai tantangan untuk } \\
\text { menunjukkan kemampuan diri }\end{array}$ & 72 \\
\hline 3. & $\begin{array}{l}\text { Memikirkan alternatif solusi/tindakan yang tidak } \\
\text { dilakukan oleh orang-orang pada umumnya }\end{array}$ & 75 \\
\hline 4. & Tidak takut untuk mencoba hal-hal baru & 72 \\
\hline 5. & $\begin{array}{l}\text { Mau belajar mempergunakan cara, teknik dan peralatan } \\
\text { baru }\end{array}$ & 73 \\
\hline 5. & $\begin{array}{l}\text { Tidak takut dicemoohkan oleh orang lain karena berbeda } \\
\text { dari kebiasaan }\end{array}$ & 78 \\
\hline 6. & $\begin{array}{l}\text { Tidak malu bertanya berbagai informasi pada sesuatu } \\
\text { hal yang dianggap menarik }\end{array}$ & 68 \\
\hline 7. & Toleran terhadap kegagalan dan frustasi & 72 \\
\hline 8. & Tidak cepat puas terhadap hasil yang diperoleh & 67 \\
\hline 9. & $\begin{array}{l}\text { Melakukan suatu aktivitas secara lebih efektif, efisien, } \\
\text { dan produktif }\end{array}$ & $\begin{array}{l}\text { Melakukan sesuatu berdasar pada integrasi kejujuran, } \\
\text { menjujung sistem nilai, bertujuan positif }\end{array}$ \\
\hline 10. & Total rata-rata & $737 / 10=\mathbf{7 3 , 7}$ \\
\hline
\end{tabular}

\section{Pembahasan}

Berdasarkan hasil analisis data yang dihitung secara sederhana tersebut maka diperoleh data berdasarkan urutan nomor indikator perilaku, yaitu (a) Memiliki gagasan-gagasan baru dan dikombinasikan dari pengalaman masa lalu yang dihubungkan dengan situasi sekarang, memiliki peningkatan sebesar $(70-60)=10$. Peningkatan pada prilaku nomor (a) ini cukup besar, bila dibandingkan dengan nomor lainnya. Hal itu menunjukkan indikasi, bahwa responden (dalam hal ini pengawas madrasah) memang banyak yang telah berpengalaman atau masa kerja kepengawasannya relatif lama. Namun demikian, pengawas madrasah memang perlu dimotivasi terus-menerus agar dapat membuahkan gagasangagasan baru dalam menjalankan tugas pokoknya. (b) Melihat suatu persoalan sebagai tantangan untuk menunjukkan kemampuan diri, memiliki peningkatan sebesar (72$65)=7$. Peningkatan pada perilaku nomor (b) ini tidak besar. Hal itu kemungkinan dipicu oleh faktor 
latar belakang geografi tempat tinggal, tempat atau wilayah binaan, usia, dan pendidikan. (c) Memikirkan alternatif solusi/ tindakan yang tidak dilakukan oleh orang-orang pada umumnya, memiliki peningkatan sebesar (75$61)=6$. Pada item perilaku nomor (c) sebenarnya merupakan tugas dan tanggung jawab pengawas madrasah dalam membina para gurunya. Namun demikian, banyak faktor yang menyebabkan pengawas madrasah kurang memikirkan alternatif solusi/ tindakan, misalnya kurangnya waktu, keterjangkauan wilayah binaan. (d) Tidak takut untuk mencoba hal-hal baru, memiliki peningkatan sebesar $(70-65)$ $=5$. Item perilaku nomor (d) hanya meningkat 5 poin. Hal itu menunjukkkan pengawas perlu terus dimotivasi dan di up date wawasan berpikirnya (e) Mau belajar mempergunakan cara, teknik dan peralatan baru, memiliki peningkatan sebesar $(70-65)=5$. Pada nomor (e) ini pun hanya meningkat 5 poin. Hal itu mungkin disebabkan faktor keterbatasan waktu. (f) Tidak malu bertanya berbagai informasi pada sesuatu hal yang dianggap menarik, memiliki peningkatan sebesar $(73-60)=7$. Untuk item nomor (f) hanya meningkat 7 poin. Hal itu menunjukkan, bahwa masih ada pengawas madrasah yang gengsi untuk bertanya halhal yang kurang dipahaminya. (g) Toleran terhadap kegagalan dan frustasi, memiliki peningkatan sebesar $(78-67)=11$. Pada item perilaku nomor (g) meningkat 11 poin, dan merupakan peningkatan tertinggi dari item perilaku lainnya. Hal itu menunjukkan bahwa pengawas madrasah adalah warga yang toleran terhadap kegagalan dan frustasi. Mungkin hal itu disebabkan para pengawas adalah orang-orang yang sudah matang emosi dan spritualnya sehingga dapat memahami para guru, kepala madrasah, dan sesama pengawas madrasah. (h) Tidak cepat puas terhadap hasil yang diperoleh, memiliki peningkatan sebesar $(68-60)=8$. Pada item perilaku nomor (h) meningkat 8 poin, dan merupakan peningkatan cukup tinggi. Hal itu menunjukkan pengawas madrasah cukup peduli terhadap warga binaannya yang belum sesuai dengan harapannya. (i) Melakukan suatu aktivitas secara lebih efektif, efisien, dan produktif, memiliki peningkatan sebesar $(72-66)=6$. Pada item perilaku nomor (i) meningkat 6 poin. Hal itu merupakan peningkatan yang tidak terlalu tinggi. Hal itu kemungkinan disebabkan letak wilayah binaannya yang saling berjauhan, sehingga keterjangkauan mengunjungi madrasah yang kurang optimal. (j) Melakukan sesuatu berdasarkan pada integrasi kejujuran, menjujung sistem nilai, bertujuan positif, memiliki peningkatan sebesar $(67-64)=7$. Pada item perilaku nomor (j) meningkat 7 poin, dan merupakan peningkatan sedang 
saja. Padahal sistem nilai yang dijunjung. Namun demikian, kita berharap pada waktu mendatang pengawas madrasah cukup peka terhadap nilai-nilai yang bertujuan positif, terutama untuk meningkatkan dunia pendidikan.

Dengan demikian, nilai ratarata dari 30 (tiga puluh) responden sebelum diberikan materi inti diklat diperoleh data 64,0; sedangkan setelah diberikan materi inti diklat diperoleh data 73,7. Berdasarkan hasil temuan tersebut, maka ada peningkatan nilai kreativitas sebesar 9,7 setelah diberikan materi inti diklat.

Dengan kata lain, dari 30 (tiga puluh orang peserta Diklat Teknis Substantif Pengawas Madrasah Madya Angkatan I, setelah diberikan materi inti baik dalam bentuk ceramah, diskusi dan simulasi, maka meningkat kreativitasnya dari 64,0 menjadi 73,7. Atau terjadi peningkatan nilai kreativitas sebesar 9,7 setelah diberikan materi inti diklat.

\section{PENUTUP}

\section{Simpulan}

Berdasarkan uraian di atas dapat disimpulkan, bahwa Diklat Teknis Substantif Pengawas Madrasah Madya meningkatkan kreativitas pengawas madrasah sebesar 9,7. Artinya, kreativitas peserta Diklat Teknis Substantif Pengawas Madrasah Madya meningkat setelah mendapatkan materi-materi inti.

\section{Saran}

Pengawas sebaiknya terus meningkatkan kompetensinya agar kreativitasnya terbangun dalam melaksanakan tugas kepengawasan.

Kepala Kementerian Agama Kota/Kabupaten, sebaiknya stakeholder lainnya memberikan informasi kedinasan atau informasi regulasi terbaru terlebih dahulu kepada pengawas, baru kemudian kepada kepala madrasah lalu kepada guru karena sesuai dengan fungsinya, bahwa pengawas madrasah merupakan perpanjangan tangan stakeholder dalam penyampaian info-info kedinasan. 


\section{DAFTAR PUSTAKA}

Departemen Pendidikan Nasional. Peraturan Menteri Pendidikan nasional Nomor 12 tahun 2007. Jakarta: Depdiknas.

Departemen Agama. Keputusan Menteri Agama Nomor 381 tahun 1999 tentang Jabatan Fungsional Pengawas dan Angka Kreditnya. Jakarta: Direktorat Pendidikan Agama Islam.

Enslikopedia, edisi ke sepuluh. 2003. Ilmu Pengetahuan Populer seri ke 9, Grilier Internasional, Inc. Diedarkan khusus oleh PT Widyadara.

http://www.lowongan.info/front, April 2006, Tip dan trik : memancing kreativitas

http://www.itpin.com/blog/2006/11/30, Confirmation bias dan kreativitas /2007/01/04, Empat hambatan kreativitas.

http://pepak.sabda.org/pustaka/061402/ , kegiatan kreatif untuk anakanak; (diakses tanggal 3-5-2017)

http://www.halalguide.info, Memacu kreativitas anak; (diakses tanggal 1-5-2017)

http://.e.psikologi.com/manajemen/kreativitas.htm menumbuhkan kreativitas di tepat kerja (diakses tanggal 2-4-2017)

http://www.pikiran rakyat.com/cetak/2005/1105/29/1106.htm Pembelajaran kreatif. (diakses tanggal 1-5-2017)

http://forumgurunusantara.blogspot.com/2016/02/pengertiankreativitas-proses-dan-ciri.html (diakses, 29-5-2017)

https://www.google.co.id/s?q=pengaruh+iklim+organisasi+terha dap +kreativitas+kerja + pegawai\&oq=pengaruh+iklim+org anisasi +terhadap+kreativitas +kerja+pegawai\&aqs =chrome..69i57.38675j0j4\&sourceid = chrome\&ie=UTF-8.

Keputusan Menteri Pendayagunaan Aparatur Negara Nomor 118/1996 tentang Jabatan Fungsional Pengawas sekolah dan angka kreditnya. Jakarta: Menpan.

Lumsdaine edward \& Monika. 1995. Creative Problem Solving, thingking skills for a changing world. New York: McGraw-Hill Internasional Editions. 
Mamat Supriatna. 2006. Strategi bimbingan dan konseling pengembangan aspek kepribadian siswa sekolah menengah, materi workshop bridgingcourse bimbingan dan konseling. Direktorat PSMP DirjenMPDM Depdiknas 